\title{
A PRELIMINARY SURVEY OF STAPHYLOCOCCUS AUREUS INFECTION IN GOATS WITH MASTITIS IN "NOUQRA" VALLEY OF ASWAN GOVERNORATE, SOUTH EGYPT
}

\author{
A.M.A. ZAITOUN ${ }^{1}$; A.E.A. ABD-EL-WAHED ${ }^{2}$; ALSAGHER O. ALI ${ }^{2}$ \\ and WALAA HUSSIEN ${ }^{3}$ \\ ${ }^{1}$ Infectious Diseases, Dept. Animal Medicine, Assiut Univ., Egypt \\ ${ }^{2}$ Dept. Animal Med., South Valley Univ., Egypt \\ ${ }^{3}$ Vet. Directorate, Edfo, Aswan Governorate, Egypt \\ This article is an abstracted outline from MV-theses presented by the fourth author to Faculty of Vet. Med., Dept. \\ Animal Med., (Infectious Diseases), South Valley University under supervision of the firs-three authors
}

Received: 30 December 2018; Accepted: 23 January 2019

\begin{abstract}
Prevalence of mastitis in goats located in Nouqra valley, Aswan Governorate, by indirect method (California Mastitis Test) in paralleling with culturing and molecular (PCR) procedures for detection of Staphylococcus aureus as a major mastitis pathogen. A total of 148 raw milk samples were subsequently collected from apparently healthy native breed goats, with different age and parity, and subjected to California Mastitis Test. By CMT, our results indicated that $117(79.05 \%)$ of the tested-samples were positive. Culturally using Baired Parker media, pure strains of Staphylococcus aureus was isolated from CMT-positive samples with a percentage of $1.35 \%$ and $77.7 \%$ of the samples showed fair growth, which classified as other non-aureus staphylococci. Coagulase test revealed 7 (4.7\%) samples were positive and $141(95.3 \%)$ were negative. These isolates were molecularly tested using 16s Rrna (Staphylococcus genus specific), nuc gene (S.aureus species specific) and mecA gene (methicillin resistance gene) by Multiplex PCR Technique. Their results indicated that $87.5 \%$ were positive for 16 s Rrna, $25 \%$ were positive for nuc gene, $75 \%$ were positive for mec $A$ gene and $12.5 \%$ were negative. The in-vitro antibiotic sensitivity testing revealed that the resistant percentages to penicillin were surprise $(100 \%$ resistance). Amoxicillin, cefaclore, colistin, oxolinic acid, neomycin, erythromycin, and lincomycin were also examined with various resistant results. Approx. $85 \%(85.71 \%)$ of the tested strains were Ciprofloxacin-sensitive.
\end{abstract}

Key words: Preliminary survey, Staph aureus, antibiotic resistance, mecA, Nuc genes, mastitis

\section{INTRODUCTION}

Mastitis is still frequently incriminated as one of the most important threats affecting the world's dairy industry (Serrano-Rodríguez, 2017) inducing colossal damages to livestock production (Samiullah et al., 2000). There are two form of mastitis; clinical and subclinical forms. The later appears to be more prominent (Willium et al., 1987). Various pathogens are encountered as etiologic agent of mastitis. Based on the principal reservoirs of mastitogens, mastitis was into environmental and contagious mastitis (Hogan and Smith, 2012). The later appears to be more prominent than the former. Staphylococcus

Corresponding author: A.M.A. ZAITOUN

E-mail address: amazaitoun@aun.edu.eg.

Present address: Infectious Diseases, Dept. Animal Med., Faculty Assiut Univ. aureus is frequently incriminated as a serious mastitogen of milk producing goats and ewes, particularly in sublevel hygienic measures (Salaberry SR, 2015 and Serrano-Rodríguez, 2017).

Small ruminants particularly goats are more populated animals than other ruminants in El Nouqra valley. This valley is one of the oldest Egyptian valleys located in Eastern border of Nasr El Nouba and Draw centers, neighbor to "Khirt Valley" of Aswan Governorate and west to the desert of the Red Sea Governorate in South Egypt (GIS, 2013), (Fig. 1). 


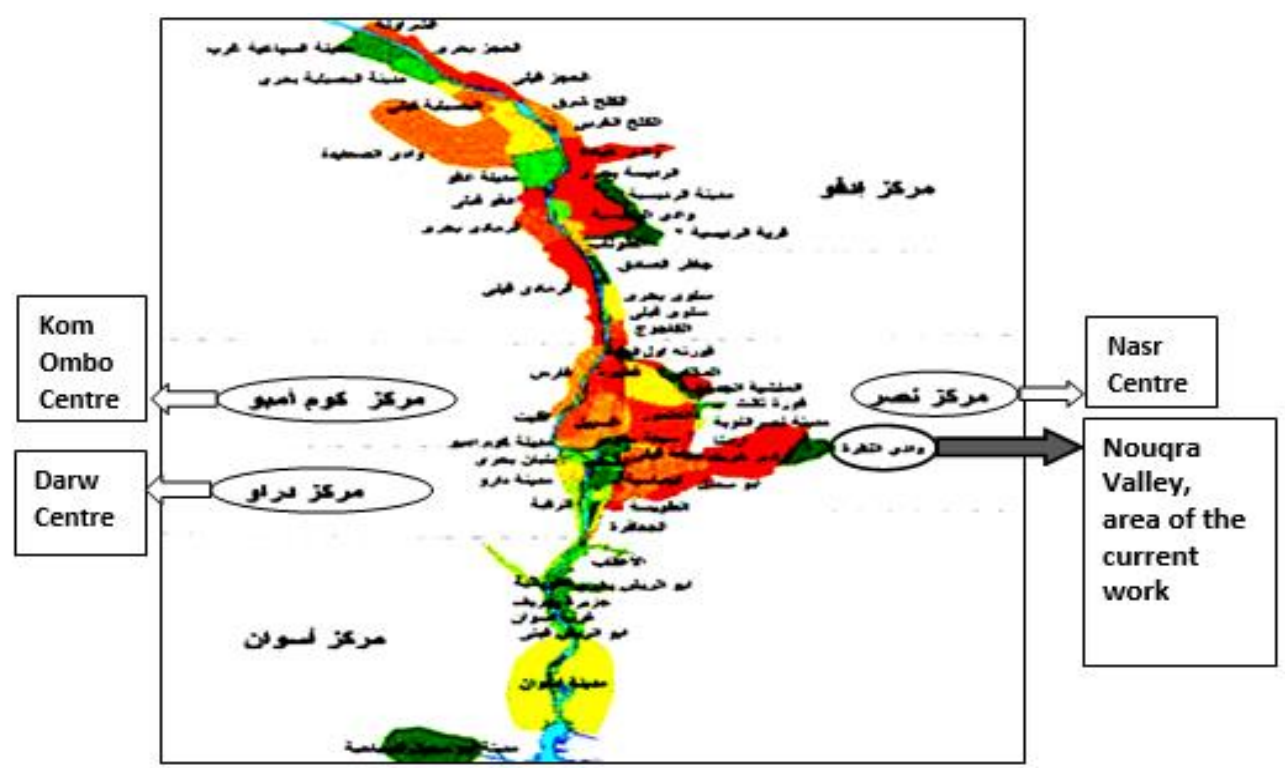

Fig. 1: Centers of Aswan Governorate indicating the location of "Nouqra" Valley

The average public economic income of the working people in Nouqra valley is low (GIS, 2013) and the most people prefers goats for milk and meat productions. Moreover, Nouqra's peoples assumed that goats have more resistance to dry and harsh environmental conditions in comparison with sheep and other large ruminates. In Nouqra valley, goat's milk considers a preeminent food with a considerable level of nutritional value. Therefore, the aim of the current work was carried out to reveal-up the prevalence of subclinical mastitis in goats by indirect method (California Mastitis Test) in association with culturing technique focusing on Staphylococcus aureus. The isolated strains were molecularly tested to mecA gene and nuc gene of Staphylococcus aureus using PCR with species specific primers. In-vitro antibiotic sensitivity tests for the isolated Staphylococcus aureus was also done.

\section{MATERIALS AND METHODS}

A total of 148 milk samples were subsequently collected from goats of local breeds apparent normal goats with different age and parity Table (1\& 3), There were four cases $(2.7 \%)$ with clinical mastitis and $144(97.3 \%)$ were apparent healthy cases. Milk samples were collected in sterile single use disposable falcon tubes with tightly fitted caps, all samples subjected to California Mastitis Test, then frozen immediately at $-20^{\circ} \mathrm{c}$ (Pamela, 2005)

Table 1: Age-wise distribution of goat age and their percentage.

\begin{tabular}{ccc}
\hline Age (years) & No. of female goats & \% to all $(\mathbf{n}=\mathbf{1 4 8})$ \\
\hline$>\mathbf{1}-\mathbf{2}$ & 58 & 39.19 \\
\hline$>\mathbf{2}-\mathbf{3}$ & 41 & 27.70 \\
\hline$>\mathbf{3}-\mathbf{4}$ & 18 & 12.16 \\
\hline$>\mathbf{4}$ & 31 & 20.94 \\
\hline Total & 148 & 100 \\
\hline
\end{tabular}

Table 2: Average number of birth (parity).

\begin{tabular}{ccc}
\hline Parity & No. of female goats & \% to all $(\mathbf{n}=\mathbf{1 4 8})$ \\
\hline 1 birth & 23 & 15.54 \\
\hline 2 birth & 41 & 27.70 \\
\hline 3 birth & 32 & 21.62 \\
\hline 4 birth & 30 & 20.27 \\
\hline 5 birth & 22 & 14.86 \\
\hline Total & 148 & 100 \\
\hline
\end{tabular}




\section{Culturing of S.aureus}

S.aureus was confirmed on baird-parker media according to (Lancette and Bannette, 2001), typical large black colonies appeared and 3-4 colonies kept in glycerol broth at -70 to $-80^{\circ} \mathrm{c}$ for further identification. The coagulase test was performed by two different methods; the slide and tube coagulase test (Cookson, 1997).

\section{Antibiotic sensitivity test}

S.aureus strains which had been isolated and confirmed with coagulase test (positive samples) had been tested for it's susceptibility to antibiotics by disc diffusion method (Bauer et al., 1966) and (Dereesse et al., 2012), by using Muller Hinton Agar and the diameter of the zones were measured and compared (NCCLS, 2001).

Primer used in PCR assay:

Application of PCR for identification of 16srRNA, nuc gene (general primer) and mec A gene of $S$. aureus was carried out by using Primers as showen in the following table:

Table 3: Primers used in PCR assays.

\begin{tabular}{|c|c|c|c|}
\hline Target & $\begin{array}{l}\text { Name } \\
\text { (strand) }\end{array}$ & Primer sequence (5 - 3) & Reference \\
\hline \multirow{2}{*}{ Staphylococcus } & 16S rRNA -F & 5'-GTA GGT GGC AAG CGTTAT CC -3' & \multirow{2}{*}{$\begin{array}{l}\text { Monday and } \\
\text { Bohach (1999) }\end{array}$} \\
\hline & 16S rRNA -R & 5'- CGC ACA TCA GCG TCA G -3' & \\
\hline \multirow{2}{*}{ Staph aureus } & Nuc 1 & 5'- GCG ATT GAT GGT GAT ACG GTT-3' & \multirow{2}{*}{$\begin{array}{c}\text { Brakstad et al. } \\
\quad(1992)\end{array}$} \\
\hline & Nuc 2 & 5'- AGC CAA GCC TTG ACG AAC TAA AGC-3' & \\
\hline \multirow{2}{*}{$\begin{array}{l}\text { Methicillin } \\
\text { resistance }\end{array}$} & Mec A- F & 5'-GTG AAG ATA TAC CAA GTG ATT-3' & \multirow{2}{*}{$\begin{array}{l}\text { Zhang et al. } \\
\quad(2005)\end{array}$} \\
\hline & Mec A- R & 5'-ATG CGC TAT AGA TTG AAA GGA T-3' & \\
\hline
\end{tabular}

Detection of 16s rRNA, mecA gene and nuc gene Using Multiplex PCR method for detection of $16 \mathrm{~s}$ rRNA of Staphylococcus genus specific, nuc gene for S.aureus species specific and mecA gene for detection of methicillin resistant S.aureus.

1. DNA extraction: A boiling procedure to the pellet at $100^{\circ} \mathrm{c}$ for 20 minutes was used to extract DNA from bacterial isolates according to Reischl et al. (1994).

2. DNA amplification reaction: Multiplex $P C R$ assay was performed By using total volume of $25 \mathrm{ul}$ reaction mix contain $5 \mathrm{ul}$ of template DNA, $20 \mathrm{pmol}$ of each primer and $1 \mathrm{X}$ of PCR mix. The PCR cycles were carried out in Eppendorf AG (22331 Hamburg) thermocycler. The analysis of PCR products was carried out using $1.5 \%$ ethidium bromide stained agarose gel. This technique consists of repetitive cycles, where each cycle of PCR synthesis involves three steps: heat denaturation, annealing and extension.

3. Agarose gel electrophoresis: The agarose gel electrophoresis was performed according to Sambrook and Russell (2001). First: agarose gel is prepared and casted with concentration appropriate for the size of DNA fragments to be separated. Second: the DNA samples are loaded into the sample wells and the gel is run at a voltage and for a time period that will achieve optimal separation. Third: the gel is stained either by incorporation of ethidium bromide into the gel or electrophoresis buffer during electrophoresis or by submerging in buffer containing ethidium bromide after electrophoresis, then visualized directly upon illumination with UV light.

\section{RESULT}

All samples collected were tested by California Mastitis Test (CMT) as shown in table (4).

Table 4: CMT of collected milk samples.

\begin{tabular}{rrrrr}
\hline \multicolumn{1}{l}{ Samples } & & CMT positive & \multicolumn{2}{c}{ CMT negative } \\
\hline \multirow{2}{*}{148} & NO. & $\%$ & NO. & $\%$ \\
\cline { 2 - 6 } & 117 & 79.1 & 31 & 20.9 \\
\hline
\end{tabular}

By conventional culture methods on baired parker agar (table5), Two (2) samples show the characteristic colonial growth of S.aureus, 115 samples show fair growth, small black colonies and no clear zones (other staphylococci). Thirty one samples were negative. 
Table 5: Frequency of the isolated S. aureus from the examined milk samples.

\begin{tabular}{|c|c|c|c|c|c|c|}
\hline \multirow[t]{2}{*}{ NO. of tested milk samples } & \multicolumn{4}{|c|}{ Positive } & \multirow{2}{*}{\multicolumn{2}{|c|}{ Negative }} \\
\hline & $S$. & & Oth & cocci & & \\
\hline \multirow[t]{2}{*}{148} & NO. & $\%$ & NO. & $\%$ & NO. & $\%$ \\
\hline & 2 & 1.35 & 115 & 77.7 & 31 & 20.9 \\
\hline
\end{tabular}

All staphylococci isolates were tested by slide and tube coagulase test to differentiate between coagulase positive and coagulase negative staphylococci, and found that 7 samples are positive for coagulase test and 110 samples negative for coagulase test as shown in table (6). Coagulase positive staphylococci isolates were tested for sensitivity test to 12 different antimicrobials as shown in Table (7).
All Staphylococcus spp. isolated from examined raw milk samples were subjected to PCR (Multiplex PCR) for detection of 16s rRna (for Staphylococcus genus specific), nuc gene (S.aureus species specific) and mecA gene (methicillin resistance gene), two isolates of total 7 isolates tested confirmed as $S$. aureus (table 8). Six (6) isolates are positive for mecA gene. Which appear as clear bands on agarose gel at a74bp compared to molecular weight marker (Figures 1, 2).

Table 6: Results of coagulase test.

\begin{tabular}{cccccc}
\hline \multirow{2}{*}{ No. of sample } & \multicolumn{2}{c}{ Coagulase(+ve) } & \multicolumn{2}{c}{ Coagulase(-ve) } \\
\cline { 2 - 5 } & NO. & $\%$ & NO. & $\%$ \\
\hline 117 & 7 & 6 & 110 & 94 \\
\hline
\end{tabular}

Table 7: The frequency of resistance to various antimicrobials ( $\mathrm{n}=7$ isolates).

\begin{tabular}{ccccccc}
\hline \multirow{2}{*}{ Antimicrobial agents } & \multicolumn{3}{c}{$\mathbf{S}$} & \multicolumn{1}{c}{ I } & \multicolumn{2}{c}{ R } \\
\cline { 2 - 7 } & NO. & \% & NO. & \% & NO & $\%$ \\
\hline Amoxicillin (AX) & 1 & 14.29 & - & - & 6 & 85.71 \\
\hline Cefaclore (CEC) & 1 & 14.29 & - & - & 6 & 85.71 \\
\hline Ciprofloxacin (CIP) & 4 & 57.14 & 2 & 85.57 & 1 & 14.29 \\
\hline Colistin (CT) & 1 & 14.29 & - & - & 6 & 85.71 \\
\hline Erythromycin (E) & 5 & 71.43 & 1 & 14.29 & 1 & 14.29 \\
\hline Lincomycin (L) & 5 & 71.43 & 1 & 14.29 & 1 & 14.29 \\
\hline Neomycin (N) & 2 & 28.57 & 1 & 14.29 & 4 & 57.14 \\
\hline Oxolinic acid (OA) & 1 & 14.29 & - & - & 6 & 85.71 \\
\hline Penicillin (P) & - & - & - & - & 7 & 100 \\
\hline Tetracyclin (TE) & 1 & 14.29 & - & - & 6 & 85.71 \\
\hline
\end{tabular}

S. Susceptible I. Intermediate R. Resistant

Table 8: $S$. aureus isolates as diagnosed by PCR method.

\begin{tabular}{ccccc}
\hline \multirow{2}{*}{ No. of the tested S.aureus } & \multicolumn{3}{c}{ Positive } & \multicolumn{2}{c}{ Negative } \\
\cline { 2 - 5 } & NO. & $\%$ & NO. & 75 \\
\hline 8 & 2 & 25 & 6 & 75 \\
\hline
\end{tabular}




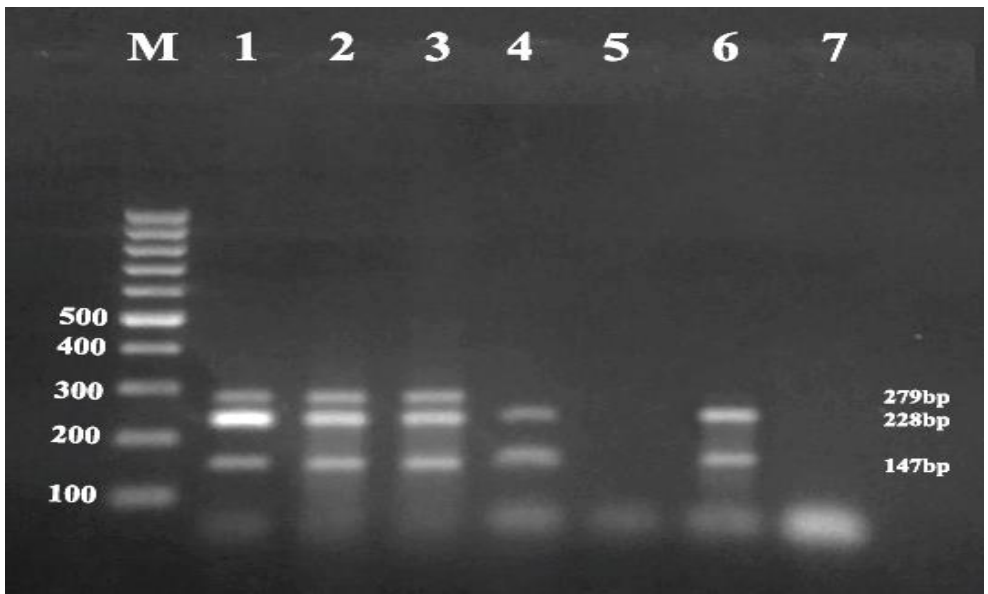

Figure (1): PCR of nuc and mecA gene on agarosegele electrophoresis. Lane M: 100bp DNA plus ladder, Lane 1: Positive control contain 3 band (147, 228 and 279bp), Lane 2, 3: isolates contain 3 bands of (147, 228 and $279 \mathrm{bp}$ ) of staphylococcus aureus and mec A gene, Lane 4, 6: contain two band of (228 and 147bp) of staphylococcus but not auerus and mec A gene, Lane 5: Negative sample, Lane 7: Negative control.

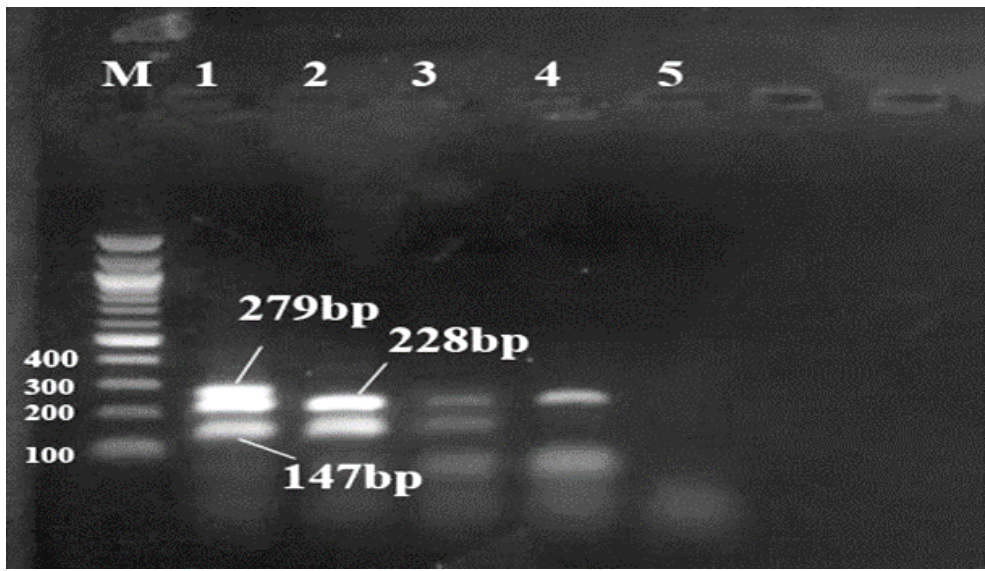

Figure (2): PCR of nuc and mecA gene on agarose gel electrophoresis. Lane M: 100bp DNA plus ladder, Lane 1: Positive control contains 3 band (147, 228 and 279), Lane 2, 3: isolates contain bands of (228 and 147) of staphylococcus but not auerus and mec A gene, Lane 4: contain one band of 228 of staphylococcus but not auerus, Lane 5: Negative control.

\section{DISCUSSION}

Staphylococcus aureus-Mastitis is a widespread disease of milk producing animals including goats (Salaberry, 2015) and is associated with a significant reduction in milk yield and deteriorated milk quality. The disease results in partial or complete damage to udder tissues and decreases the productive life span of the animal (Gonzalez et al., 1980).

Currently, culturing 148 milk samples collected from mastitic and apparent normal udder of dairy goats indicated that $117(79.1 \%)$ samples gave positive result with California mastitiic test (CMT) and appear growth on baird parker agar media. Other microorganisms can produce black colonies on baired parker agar media as Enterococcus fecalis and proteus mirabilis (Baired-parker, 1992). This is agreement with (Maya et al., 2013) who found other staphylococci grow on baired parker agar as ( $\mathrm{S}$. schleiferi). and dis agreement with (Al-azem et al., 2013) who recorded a higher percentage of isolated strains were S. aureus (95.5\%) on baired parker agar.7 isolates are staphylococcus species which gave positive result with coagulase test. The production of coagulases and thermonucleases are not unique features of S.aureus but are shared by S.intermedius and S.hyicus (El- Jakee et al., 2008).

Prevalence of subclinical mastitis of goat's raw milk obtained from Nokra Valley, Aswan Governorate, Egypt is $76.35 \%$ this result is similar to that observed by (Vasiu, 2008) as he recorded the prevalence of subclinical mastitis was $70.21 \%$, and higher than that recorded by (Contreras et al., 2007; Leitner et al., 2008; Bagnika et al., 2011). They found the prevalence of subclinical mastitis in goat is usually between 5 to $30 \%$. Indiscriminate use of antibiotics has led to ineffectiveness of antibiotic treatment (Ali et al., 2010).

Resistance of staphylococci to methicillin and all $\beta$ lactam antibiotics is associated with the low affinity of a penicillin-binding protein, $\mathrm{PBP} 2 \mathrm{a}$, which is not 
present in susceptible staphylococci. Pierre et al. (1990); Unal et al., 1992; Chamber, (1997). This protein is encoded by the mecA gene. Mastsuhashi (1986), is the corner-stone responsible for producing MRSA phenomenon (Ubkata et al., 1989; BergerBachi 1997).

It is concluded that, Staphylococcus aureussubclinical mastitis is seriousness problem in goat's population in the area of study. The misuse of antimicrobial agents leading to the development of resistant isolates which may be transmitted to the human beings causing somber troubles. Amplification of DNA by PCR is a rapid and sensitive method for the detection of specific DNA sequences.

\section{REFERENCES}

Al-Azeem, M.W.; Hazem Mahmoud Shaheen, Karima Galal Abd Hameed and Manar Mahmoud Helmy (2013): Penicillin resistance against Staphylococcal isolates recovered from subclinical mastitis in Sohag City, Egypt. Asian J Res Chem. 1: 116-130.

Ali, Z.; Muhammad, G.; Ahmed, T.; Khan, R.; Naz, S.; Anwar, H.; Farooqi, A.F.; Manzoor, N.M. and Usama, A. (2010): Prevalence of caprine sub- clinical mastitis, it's Etiological agents and their sensitivity to Antibiotics in indigenous Breeds of koht, Pakistan. Pak. J. Life Soc. Sci. 8(1): 63-67.

Bagnicka, E.; Winnicka, A.; Jozwik, A.; Rzewuska, M.; Strzalkowska, N.; Kosciuczuk, E.; Prusak, B.; Koba, J.; Horbanczuk, J. and Krzyzewski, J, (2010): Relationship between somatic cell count and bacterial pathogen in goat milk. Small Rumin Res 100(1): 72-77.

Baird-Parker, A.C. (1962): An improved diagnostic and selective medium for isolating coagulasepositive staphylococci. J. Appl. Bacteriol. 25: 12-19.

Bauer, A.W.; Kirby, W.M.; Sherris, J.C. and Tureck, M. (1966): Antibiotic susceptibility testing by a standerized single disk method. American Journal of Clinical Pathology 45: 493-496.

Brakstad, O.G.; Aasbakk, K. and Maelamd, J.A. (1992): Detection of staphylococcus aureus by polymerase chain reaction amplification of nuc gene. J Clin Microbiol; 30(7): 16541660.

Berger-Bächi, B. (1997): Resistance not mediated by $\beta$-lactamase (methicillin resistance). In The Staphylococci in Human Disease, (Crossley, K. B. \& Archer, G. L., Eds), pp. 158-74. Churchill Livingstone Inc., New York.

Chambers, H.F. (1997): Methicillin resistance in staphylococci: molecular and biochemical basis and clinical implications. Clinical Microbiological Reviews 10, 781-91.
Contreras, A.; Sierra, D.; Corrales, J.C.; Sanchez, A.; Marco, J.C.; Paape, M.J. and Gonzalo, C. (2007): Mastitis in small ruminants. Small Rumin Res 68: 145-153.

Cookson, B.D. (1997): Staphylococcus aureus. In principles in clinical bacteriology, edited by M. Emmerson, C. Kibbler and P. Hawkey, John Willey Oxford 109-130.

Deresse, D.; Solomon, G.S. and Dawit, Y. (2012): Antibiotic-resistance Staphylococcus aureus isolated from cow's milk in the Hawasse area, South Ethiopia. Ann. Clin. Microbiol. and Antimicrobials, 11: 26-34.

El-Jakee, J.; Nagwa, A.S.; Bakry, M.; Zouelfakar, S.A.; Elgabry, E. and Gad El-Sead, W.A. (2008): Characteristics of Staphylococcus aureus Strains Isolated from Human and Animals Sources, American-Eurasian J. Agric \& Environ. Sci., 4(2): 221-229.

GIS (2013): http://www.aswan.gov.eg/DocLib9/ Forms/AllItems.aspx?SortField=Title\&SortD ir $=$ Desc $\&$ View $=\% 7 B 77$ A8C4D1\%2D081A\% 2D4508\%2DAD81\%2D83675B32EE64\%7D

Gonzalez, R.N.; Giraudo, J.A. and Busso, J.J. (1980): Investigation of sub-clinical mastitis in Argentia. II. Bacterial agents. Revista Demechieine Vet. Argentia, 61(3): 225-234.

Hogan, J. and Smith, KL. (2012): Managing environmental mastitis. Vet Clin North Am Food Anim Pract., 28, 2, 217 - 24.

Lancett, G.A. and Bennet, R.W. (2001): Staphylococcus aureus and staphylococcal enterotoxins. In: Downes, F.P. and Ito, K. (Eds). Compendium of methods for the microbiological examination of foods, $4^{\text {th }}$ edition. American Public Health Association (APHA). Washington, D.C.USA.

Leitner, G.; Merin, U. and Silanikove, N. (2008): Changes in milk composition as affected by subclinical mastitis in goats. J Dairy Sci. 87,1719-1726.

Matsuhashi, M.; Song, M.D.; Ishino, F.; Wachi, M.; Doi, M. and Inoue, M. (1986): Molecular cloning of the gene of a penicillin-binding protein supposed to cause high resistance to beta-lactam antibiotics in Staphylococcus aureus. Journal of Bacteriology. 167, 975978.

Maya, Nadimpalli, Christopher H. and Jill, R.S. (2013): Identification of Staphylococcus aureus from enriched nasal swabs within $24 \mathrm{~h}$ is improved with use of multiple culture media. J. Med Microbiol. 10.

Monday, S.R. and Bohach, G.A. (1999): Use of multiplex PCR to detect classical and newly described pyrogenic toxin genes in staphylococcal isolates. J. Clinical Mirobiol., 37, 10, 3411-3414

National Committee for Clinical Laboratory Standerds "NCCLS" (2001): Performance Standards for antimicrobial susceptibility 
testing. Supplement M100-S11. Villanova, PA, ASA.

Pamela Ruegg (2005): Evaluating the Effectiveness of Mastitis Vaccines. University of Wisconsin - Madison. 3-28.

Pierre, J.; Williamson, R.; Bornet, M. and Gutmann, L. (1990): Presence of an additional penicillin-binding protein in methicillinresistant Staphylococcus epidermidis, Staphylococcus haemolyticus, Staphylococcus hominis, and Staphylococcus simulans with a low affinity for methicillin, cephalothin, and cefamandole. Antimicrobial Agents and Chemotherapy 34, 1691-4.

Reichi, U.; Pluze, M.; Ethret, W. and Wolf, $H$. (1994): PCR-based detection of mycobacteria in sputum samples using a simple and reliable DNA extraction protocol. Bio. Techniques, 17: 844-845.

Salaberry, SR.; Saidenberg, AB.; Zuniga, E.; Melville, PA.; Santos, FG.; Guimarães, EC.; Gregori, F. and Benites, NR. (2015): Virulence factors genes of Staphylococcus spp. isolated from caprine subclinical mastitis. Microb Pathol., 85, 35-39.

Sambrook, J. and Russel, D. (2001): Molecular Cloning: A Laboratory Manual, 3rd edition, Vol 1and 2, Cold Spring Harbor Laboratory Press, New York, USA.

Samiullah, M.; Syed, U.D.; Arif, M. and Khan, M. (2000): Frequency and causes of culling and mortality in Holstein and Friesian cattle In N WFP (Pakistan). J. Anime. Health. Prod., 2000, 20: 22-24.

Schaerer, W. and Maurer, J. (2006): Prevelence of subclinical udder infection and individual somatic cell counts in three dairy goat herds during a full lactation. Schweiz Arch Tierh 148: 641-648.

Serrano-Rodríguezl, JM.; Cárceles-García, C.; Cárceles-Rodríguez, CM.; Gabarda, ML.; Serrano-Caballero, JM. and FernándezVarón, E. (2017): Susceptibility and PK/PD relationships of Staphylococcus aureus strains from ovine and caprine with clinical mastitis against five veterinary fluoroquinolones. Vet Rec., 180, 15, 376. https://veterinaryrecord.bmj.com/content/180 /15/376.long

Shearer, J.K. and Harris, J.R.B. (2003): Mastitis in dairy goats. Anim. Sci. Dept. Florida coop. Ext. Serv. Inst. Food Agri. Sci; Univ. Fl. Gainesville, USA. PP: 1-6.

Ubukata, K.; Nonoguchi, R.; Matsuhashi, M. and Konno, M. (May 1989): Expression and inducibility in Staphylococcus aureus of the mecA gene, which encodes a methicillinresistant S. aureus-specific penicillin-binding protein. Journal of Bacteriology. 171 (5): 2882-5.

Unal, S.; Hoskins, J.; Flokowitsch, J.E.; Wu, C.Y.; Preston, D.A. and Skatrud, P.L. (1992): Detection of methicillin-resistant staphylococci by using the polymerase chain reaction. Journal of Clinical Microbiology 30, 1685-91.

Vasiu, C.; Bogolin, I. and Bolfa, P. (2008): Relation between the geometrical mean of somatic cells from bulk milk and the prevalence of subclinical intra mammary infections in sheep and goats. Bulletin USAMV Veterinary Medicine 65: 339-344.

Watts, J.L. (1988): Etiological agent of bovine mastitis. Vet. microbial.,16-41-66.

Willium, L.; Robert, J.; Joe O'Leary and Jack, A. (1987): Mastitis and Its Control. Cooperative Extention Service, University of Kentucky, College of Agriculture, 140.

Zhang TingTing; Huang AnNing; Li JinNian; Liu XueQin; Li Lin; Yao Lu; Huang Ying and Wang WenPing. (2014): Characterization of antimicrobial resistance and enterotoxin genes in methicillin-resistant Staphylococcus aureus isolated from mastitis milk and food poisoning cases. Journal of Animal and Veterinary Advances. 13(7): 423-429.

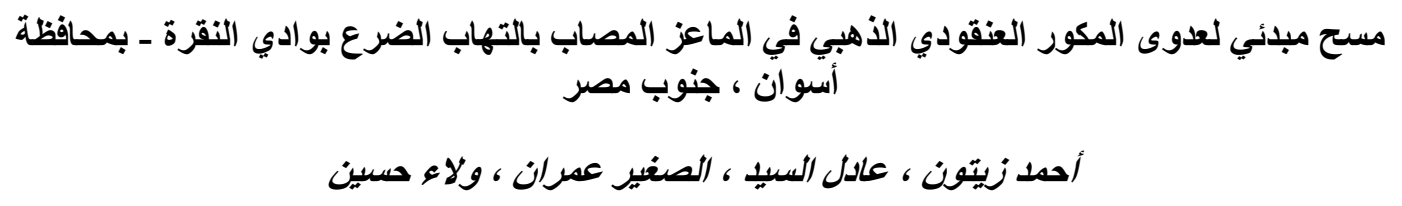

Email: amazaitoun@aun.edu.eg. Assiut University web-site: www.aun.edu.eg

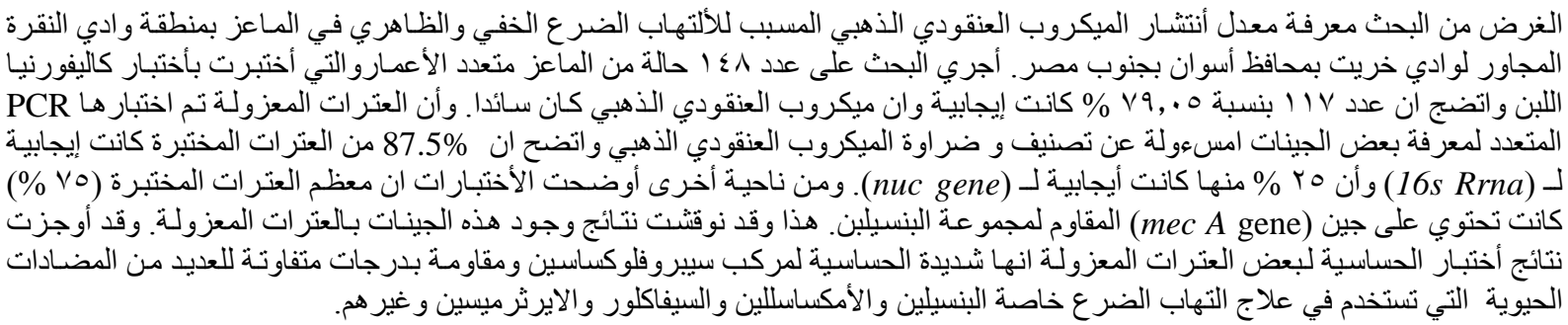

